\title{
IMAGING TROPICAL PEATLAND AND AQUIFER POTENTIAL IN SOUTH SUMATRA USING ELECTRICAL RESISTIVITY TOMOGRAPHY
}

\author{
Muhammad Rizki Ramdhani ${ }^{1 *}$, Acep Ruhimat ${ }^{1}, W_{i y o n o}{ }^{1}$, and Ahmad Barnes ${ }^{2}$ \\ ${ }^{1}$ Geological Agency, Ministry of Energy and Mineral Resources \\ Jl. Diponegoro No.57, Cihaur Geulis, Bandung, West Java, Indonesia \\ ${ }^{2}$ Peatland Restoration Agency, Jl Teuku Umar 10, Jakarta Pusat, DKI Jakarta, Indonesia
}

Received: 25 November 2019, Revised: 19 March 2020, Accepted: 21 March 2020

IMAGING TROPICAL PEATLAND AND AQUIFER POTENTIAL IN SOUTH SUMATRA USING ELECTRICAL RESISTIVITY TOMOGRAPHY. Indonesia has one of the largest tropical peatland areas in the world. In Sumatra Island, peatland spreads over 11 regions, and it is mainly found in Riau (60.1\%) and South Sumatera (19.6\%) Provinces. This study investigates the subsurface of tropical peatland in Ogan Komering Ilir Regency, South Sumatra Province. Data were recorded using Electrical Resistivity Tomography (ERT) method based on the sub-surface images of tropical peatland. This study was conducted based on the dipole-dipole configuration with 72 channels spread. This paper also studies the physical properties (thickness and electrical resistivity) of peatland and its substrate using ERT. In this study, the ERT section and the geological map identified Alluvium (Qs), Kasai Formation, and the Basement. The result shows the ERT is applicable for imaging the thickness of tropical peatland and other geological features (Aquifer, geological structures, and stratigraphy). The electrical resistivity of peat varies from 20 -ohm meter to 120 ohm meter, and the thickness of peat varies from 2-5 meters. In some ERT sections, the basement was identified from 130 meters to 170 meters beneath the surface. The aquifer sweet spots were located from ERT Sections combined with the hydrogeological map. The aquifer was identified in Kasai Formation. The thickness of the aquifer layer is $2-20$ meter. These physical properties may support peatland conservation (forest fire mitigation) and geotechnical analysis purposes.

Keywords: Electrical Resistivity Tomography, peatland, aquifer, South Sumatra

PENCITRAAN LAHAN GAMBUT TROPIS DAN POTENSI AQUIFER DI SUMATERA SELATAN MENGGUNAKAN TOMOGRAFI RESISTIVI TAS LISTRIK. Indonesia memiliki area laban gambut tropis terluas di dunia. Di Pulau Sumatera, gambut tersebar di 11 area dan yang terluas berada di Rian (60,1\%) dan Sumatera Selatan (19,6\%). Penelitian ini berlokasi di Kabupaten Ogan Komering Ilir, Provinsi Sumatera Selatan. Penelitian ini menggunakan metode Electrical Resistivity Tomography (ERT) untuk menggambarkan gambut dan kondisi bawah permukaannya. Penelitian ini menggunakan konfigurasi dipole-dipole dengan 72 elektroda. Penelitian ini bertujuan untuk. mengidentifikasisifat fisis (ketebalan dan tahanan jenis) lapisan gambut dan lapisan batuan dibawabnya dengan menggunakan metode ERT. Dari penampang ERT dan peta geologi, kami mengidentifikasi Alluvium (Qs), Formasi Kasai dan Batuan Granit. Dari hasil penelitian ini menunjukkan bahwa metode ERT ini dapat diterapkan untuk penggambaran ketebalan gambut dan fitur geologi lainya (struktur, stratigrafi, dan bidrogeologi). Hasil penelitian ini memperlibatkan resistivitas dari gambut berkisar antara 20-120 obm-meter dengan ketebalan 2-5 meter. Di penampang ERT lainnya, batuan granit dapat terlihat pada kedalaman 130-170 meter. Penentuan potensi akifer menggunakan interpretasi dari penampang ERT dan peta hidrogeologi. Potensi akifer terdapat di Formasi Kasai dengan ketebalan berkisar 2-20 meter. Properti fisik ini dapat mendukung konservasi lahan gambut dan analisis geoteknik.

Kata kunci: Electrical Resistivity Tomography, gambut, akifer, Sumatera Selatan

*Corresponding author: rizki.ramdhani@esdm.go.id 


\section{INTRODUCTION}

Generally, characteristics of tropical areas are high temperature throughout the year. In the tropics, peat occurs mostly in sub-coastal lowlands and is formed from rainforest trees and associated higher plants (Rieley \& Page, 2016). The characteristics of tropical peatland are different from mineral soil such as irreversible drying, land subsidence, low in bearing capacity, availability of nutrient, and microorganism (Agus, Anda, Jamil, \& Masganti, 2014). Tropical peatlands in their natural state are an important reservoir of biodiversity, carbon, and water (Andriesse, 1988). Indonesia contains 47\% of the global area of tropical peatland (Page, Rieley, \& Banks, 2011). In Indonesia, tropical peatlands are mostly found along the east coast of Sumatra and in the southern and western coastal regions of Kalimantan. Peatland area in Indonesia covers about 14.91 million ha spread out in Sumatra 6.44 million ha (43\%), 4.78 million ha in Kalimantan (32\%) and in Papua 3.69 million ha (25\%)(Osaki, Nursyamsi, Noor, Wahyunto, \& Segah, 2016).

Geologically, the investigation area took places in the South Sumatra Basin. Numerous geoscientists have described the tectonic setting and regional stratigraphy of South Sumatra

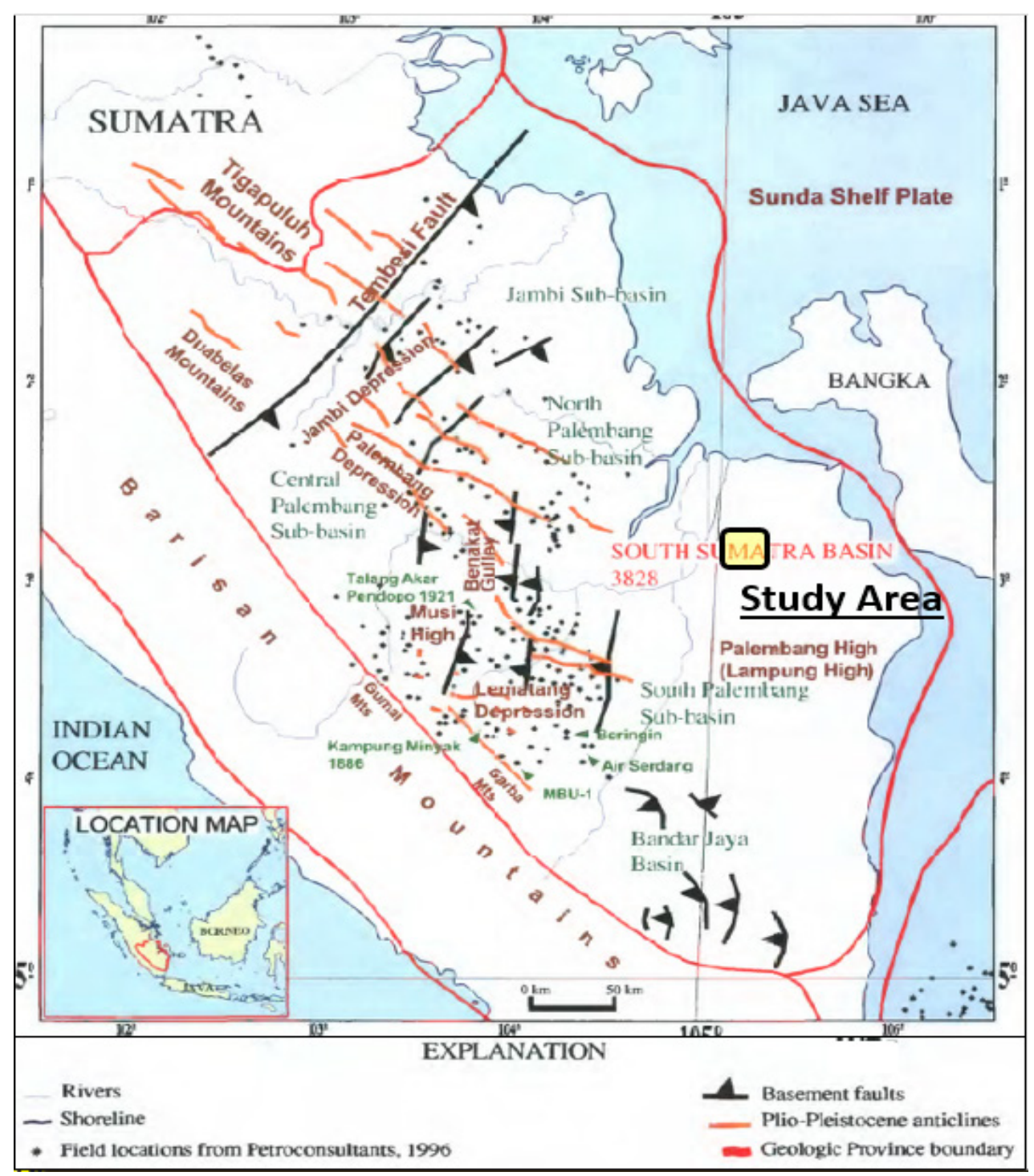

Figure 1. Location of study area in South Sumatra Basin 
Basin. The South Sumatra Basin is located to the east of Barisan Mountains and extends into the offshore areas to the northeast and regarded as a back-arc basin bounded by the Barisan Mountains to the Southwest and the pretertiary of The Sunda Shelf to the Northeast (De Coster, 1974). The South Sumatra Basin systems were formed during the Eocene Period. The tectonic setting of Sumatra was influenced by the movement and collisions of the Indian Ocean and the Southeast Asia plates. The tectonic setting of South Sumatra Basin is dominated by northwest-southeast direction fault and fold, north-south direction fault, and northeast-southwest direction fault (Figure 1). The youngest geological deposits are the Palembang Formation which is sub-divided into three parts: (1) Lower Palembang (Air Benakat Formation), Middle Palembang (Muara Enim Formation), and Upper Palembang (Kasai Formation) (Figure 2).

The Air Benakat Formation was deposited during the regression that ended the deposition of Gumai Shale (Bishop, 2001). The thickness of the Lower Palembang part (Air Benakat Formation) ranges from 100 to $1000 \mathrm{~m}$. The Muara Enim Formation was deposited as a shallow marine to continental sands, muds, and coals. The thickness of the Middle Palembang part (Muara Enim Formation) ranges 500 to $700 \mathrm{~m}$ in Muara Enim and Lahat area. The presence of the coal layer characterizes this part. The thickness of the Upper Palembang part (Kasai Formation) ranges $250-350 \mathrm{~m}$ at the lower part and $300-500 \mathrm{~m}$ at the upper part (Darman \& Sidi, 2000). The quaternary deposits may overlie the Palembang Formation. These sediments are mainly deposited in the river and swamp forest. Tropical peatlands are composed of wood from swamp forest and can be characterized as hemic to sapric (depend on the degree of decomposition). The quality, landscape (shape) and extent of peat are controlled by several factors such as vegetation type, humidity, surface-groundwater regimes, physiographic and geological setting (Cameron,

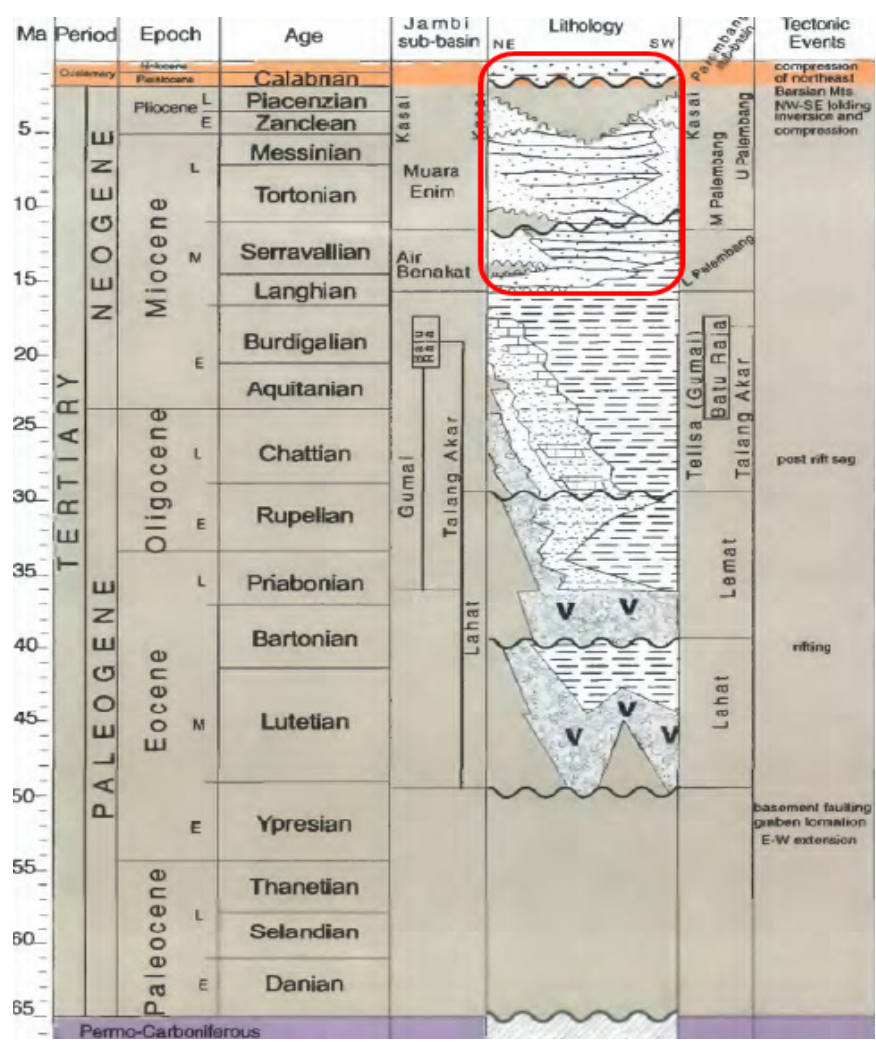

Figure 2. Stratigraphy of South Sumatra Basin and formation target of this study (Red Block) Source: Bishop (2001) 
Palmer, \& Esterle, 1990). In Sumatra, peatland is spread over 11 areas, the largest peatlands area in Sumatra, mainly in Riau (60.1\%) and South Sumatra (19.6\%). In Sumatra island, peatland area was about 6.43 million ha that was divided up as shallow peat of about 1.77 million ha, medium peat of approximately 1.71 million ha, deep peat of about 1.24 million ha, and intense peat of about 1.72 million ha (Wahyunto, Nugroho, \& Fahmuddin, 2014). In South Sumatra Province, Musi Banyuasin Regency, the thickness of peat varies from 0.3 $\mathrm{m}$ to $6.6 \mathrm{~m}$ (Subarnas \& Ibrahim, 2018).

Peatland utilization for agriculture in Indonesia has a long history. However, greenhouse gases emissions and peatland fires issues have motivated the government to limit the usage of peatland in Indonesia. Since 2012 to 2016, more than 500 hotspots from peat swamp forests were regularly detected in South Sumatra (Putra, Sutriyono, Kadir, \& Iskandar, 2019). During the dry season in 2019, at least 2000 hotspots were identified in South Sumatra (CNN, 2019). Indonesia has four principal regulations which directly affect the peatland utilization (Kittie, Schouten, \& Hein, 2018). The four regulations require the adoption and integration of quite complicated technical practices to measure peatland distribution, depth, and hydrogeology of peatland. Aquifer existence is essential for peatland restoration effort and peat fires mitigation. Based on these requirements, geophysical method (ERT) can provide the technical data through field assessment.
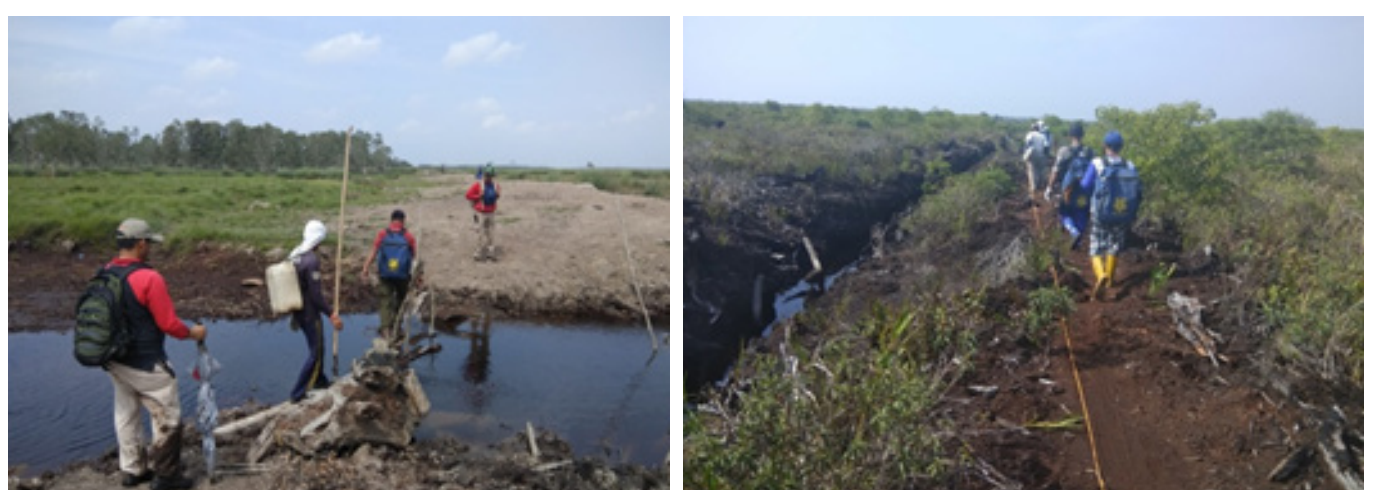

Figure 3. Location of ERT acquisition (near the burnt area) for environmental investigation (Telford, Geldart, \& Sheriff, 1990; Reynolds, 2011). Electrical Resistivity Tomography (ERT) method is potential to assist the understanding and imaging of peatland stratigraphy and hydrogeology. Some studies were investigated in northern peatland using ERT method. In Europe, Trappe and Kneisel (2019) used ERT for the assessment of lithology and subsurface water pathways. ERT and GPR were combined to identify structure, stratigraphy, hydrogeology and physical properties of peat in northern peatland (Xavier Comas, Slater, \& Reeve, 2004, 2011; Kowalczyk, Zukowska, Mendecki, \& Łukasiak, 2017; Sass, Friedmann, Haselwanter, \& Wetzel, 2010; Slater \& Reeve, 2002).

In Indonesia, ERT has been used for imaging tropical peatland in Tanjung Gunung and Pelang Village, West Kalimantan Province (Comas et al., 2015). The study sites were located in Perigi, Air Rumbai and Sungai Bungin Village, Ogan Komering Ilir Regency, South Sumatra Province. Our sites are $70 \mathrm{~km}$ from Palembang. According to the geological map of Tulung Selapan Area, our sites consist of alluvium and swamp deposit, Kasai Formation, Muara Enim Formation, Air Benakat Formation and Basement (Mangga, Sukardi, \& Sidarto, 1993).

The sites were dominated by alluvium and swamp deposits which composed of gravels, sands, clays, and peat. Underlying of swamp deposits, Kasai Formation is composed of tuff, tuffaceous sand, sandstones, and iron oxide gravel. The basement (granite) was identified

Geophysical methods are usually applied 
about $10 \mathrm{~km}$ from the investigation area (Figure 4). According to the hydrogeological map of Tulung Selapan Area, swamp deposits which are dominated by peat have low permeability (Pasaribu \& Mudiana, 2013). Kasai Formation, which composed of tuff, tuffaceous sand, and sandstones have low to moderate permeability
(Figure 5). This formation contains a potential aquifer layer. An aquifer is a saturated geological unit that can transmit water easily in significant amounts, and aquitard is a geological formation that can transfer water at slower rates than aquifer (SxEN, 2015). Perigi, Air Rumbai and Sungai Bungin villages were of the highest
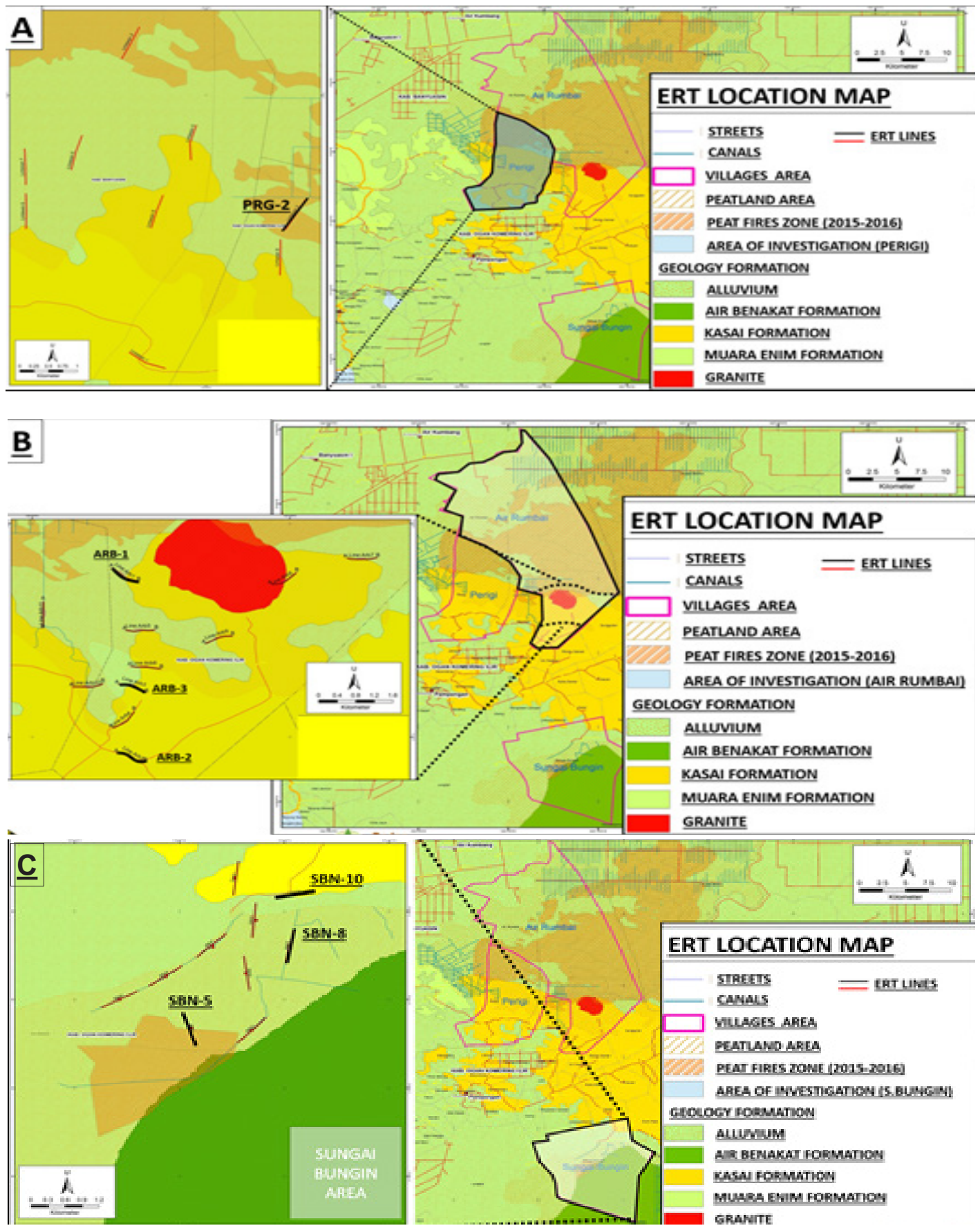

Figure 4. Geological map of Tulung Selapan Area and location of study, Perigi Village (A), Air Rumbai Village (B), and Sungai Bungin Village (C) 

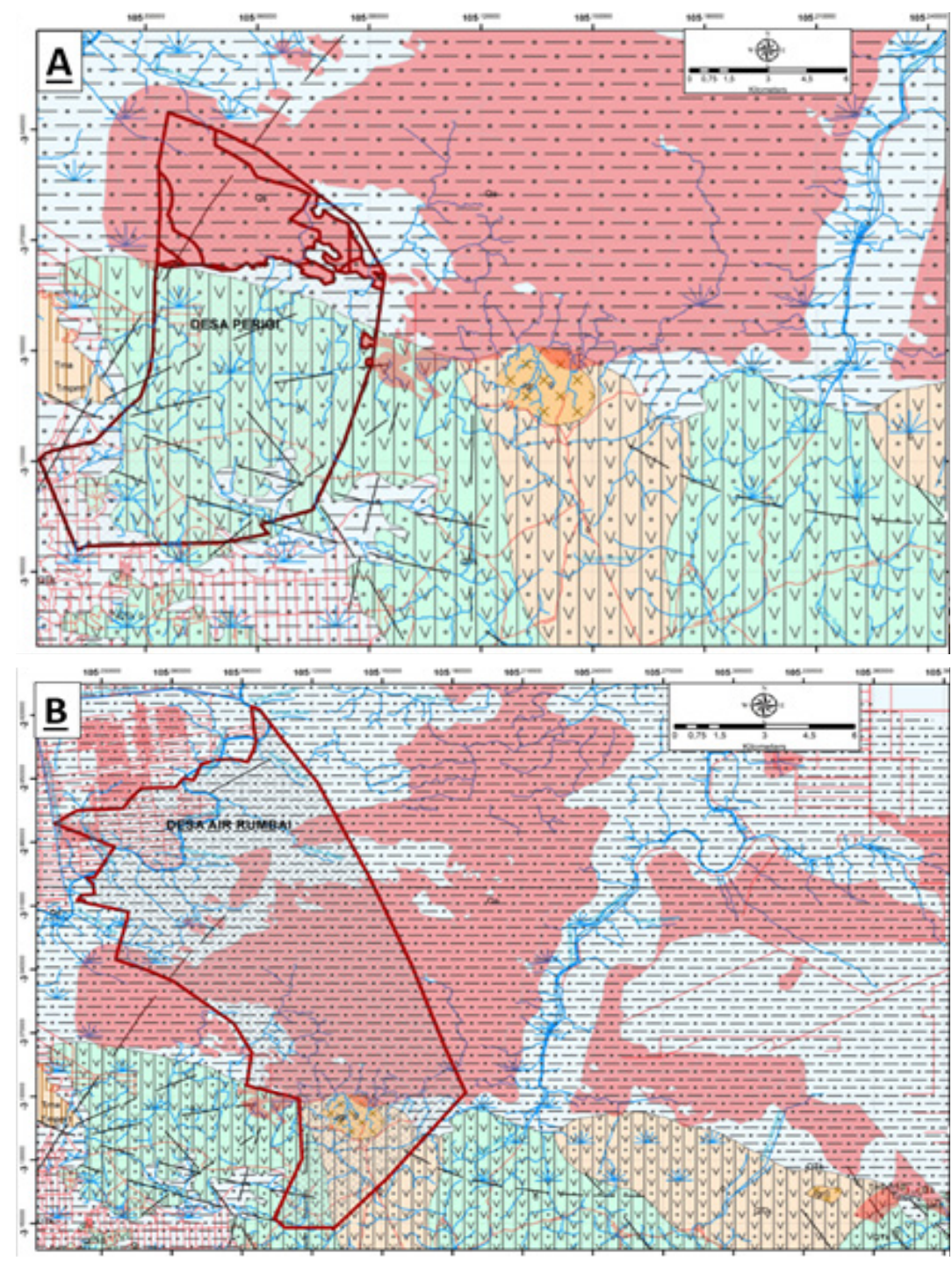

\begin{tabular}{|c|c|}
\hline \multicolumn{2}{|c|}{ LITHOLOGY \& THEIR PERMEABILITY } \\
\hline 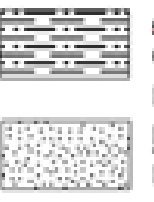 & $\begin{array}{l}\text { Aluvium \& Swamp Deposit: Gravels, Sands, } \\
\text { Clays and Peat in place. Moderate to High } \\
\text { Permeability, low in swamp deposit } \\
\text { Fine Quartz Sands: Moderate to High } \\
\text { Permeability }\end{array}$ \\
\hline & $\begin{array}{l}\text { Tuff, Tuffaceous Sands \& Iron Oxide } \\
\text { Gravels: low to moderate Permeability }\end{array}$ \\
\hline : $: 5:$ : & $\begin{array}{l}\text { Sandstone, Clayey sandstone, \& quartz } \\
\text { sandstone: Generally low Permeability, } \\
\text { locally moderate permeability in weathered }\end{array}$ \\
\hline $\begin{array}{l}x \times x \\
\text { AQUIFERS IN } \\
\text { INTERANGII }\end{array}$ & $\begin{array}{l}\text { Granite: Generally Impermeable, locally low } \\
\text { to moderate permeability in weathered or } \\
\text { fractured zone } \\
\text { N WHICH FLOW IS } \\
\text { IAR }\end{array}$ \\
\hline & Extensive, Productive Aquifers \\
\hline
\end{tabular}

AQUIFERS IN WHICH FLOW IS BOTH THROUGH FISSURES AND INTERSTICES

Locally Productive Aquifers

AQUIFERS (FISSURED OR POROUS) OF POOR PRODUCTIVITY AND REGIONS WITHOUT EXPLOITABLF GROUNDWATER

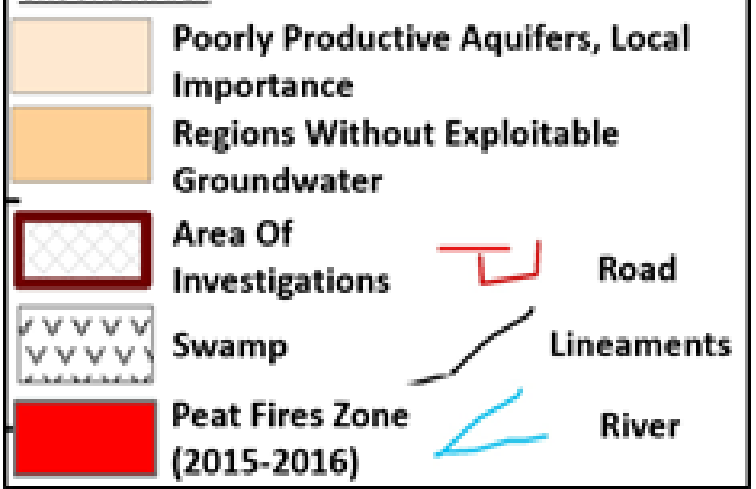



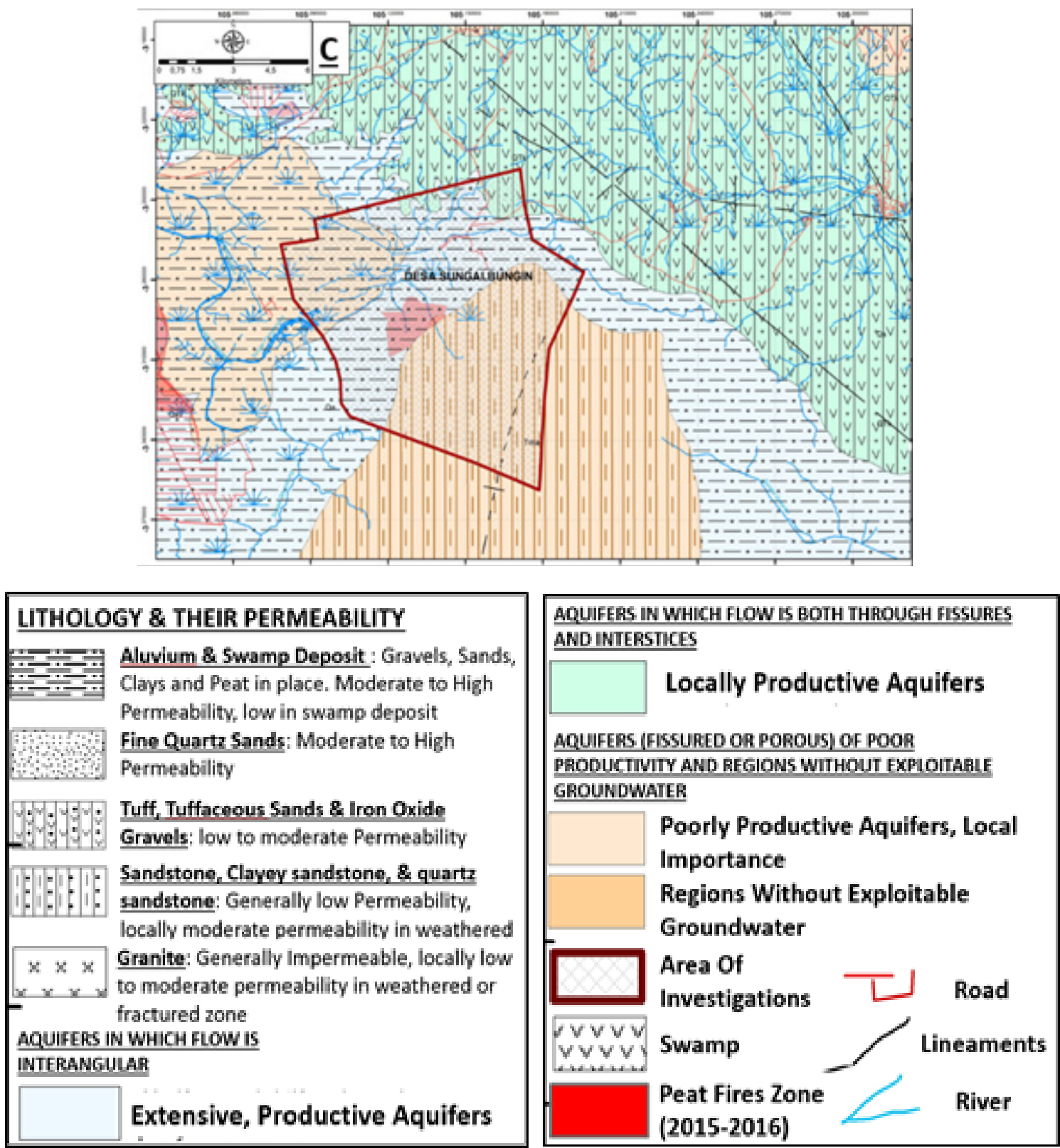

Figure 5. Hydrogeological map of Perigi (A), Air Rumbai (B) and Sungai Bungin (C)

Source: Modified from Pasaribu \& Mudiana (2013)

priority of the investigation. Peat fires have burnt almost $30 \%$ of the peatland area in Perigi Village, 50\% in Air Rumbai and Sungai Bungin Villages (Figure. 4). It is located in the southern side of of the burnt area, and about $20-40 \%$ peatland area was converted to rubber plantation. ERT measurements were conducted near the burnt area (Figure 3).

This study used electrical resistivity tomography to investigate subsurface of tropical peatland in Ogan Komering Ilir Regency, South Sumatra Province. This paper studies the Electrical Resistivity Tomography (ERT) for estimating and identifying physical properties of peat and its substrate (thickness and electrical resistivity). The method is also aiming for hydrogeological information of the peatland area. Advancing this knowledge could help to assist peatland management's decisions in Indonesia and improve assessment of peat. 


\section{MATERIAL AND METHOD}

\section{A. Electrical Resistivity Tomography}

Electrical Resistivity Tomography (ERT) is a geophysical technique for imaging subsurface structures from electrical resistivity measurements, which is made at the surface by multi electrodes. The true sub-surface resistivity could be estimated by making the measurements of potential differences at different positions of the current and potential electrodes, converting these values into apparent resistivity and then inverting the data set (Loke, 2011). The electrical resistivity of rocks depends on complex combinations of various electrical components consisting of solids (silicates, oxides, and metal), pores filled with air or liquid, and interfaces between solids and liquids (Yoshino, 2011). Peat is typically saturated and composed of $80-95 \%$ water (Hobbs, 1986). Electrical resistivity in peat depends on its physical properties such as organic and mineral content, mineral composition, moisture content, degree of peat decomposition, and water conductivity in peat matrix/pores. Tropical peat mostly consists of water with an organic carbon content (by weight) of 12 to $18 \%$, or more, depending on the clay content of the peat, and the bulk density is in the range of $0.07-0.1 \mathrm{~g} / \mathrm{cm}^{3}$ (Taufik, Veldhuizen, Wösten, \& van Lanen, 2019).

Electrical resistivity tomography was conducted using IRIS Syscal Pro 72 channel with automated data acquisition unit (Figure 6). Dipole-dipole configuration with $10 \mathrm{~m}$ electrode spacing was applied in these measurements. The sequence of measurements was made covering a total length of approximately $720 \mathrm{~m}$, providing a maximum imaged depth of about 160-180 m. This parameter was chosen because of the requirement of deeper penetration for hydrogeological study. Field data obtained by ERT measurements were processed and interpreted using Res2DINV Software (Loke, 2000). The processing involves imputing topography data, editing the wrong datum, and running the inversion. The inversion routine used the least-square algorithm. The inversion result can be presented as a block model scheme or an interpolated contour map with a colour scale. The interpretation of the ERT section was performed based on the clustering of resistivity value from study literature (Loke, 2000) and combined with the geological and hydrogeological map.

This study has conducted twenty ERT lines. Because of the limitation in publication, this paper presented only three ERT sections (PRG-2, ARB-1 and SBN-8) from Perigi, Air Rumbai and Sungai Bungin Village. All of these lines were chosen because of the variation of the geological subsurface conditions (peat thickness, lithology and aquifer potential) and near the burnt area.

\section{RESULT AND DISCUSSION}

Electrical resistivity tomography has proven applicable for detecting changes in peat thickness, identifying and estimating the depth

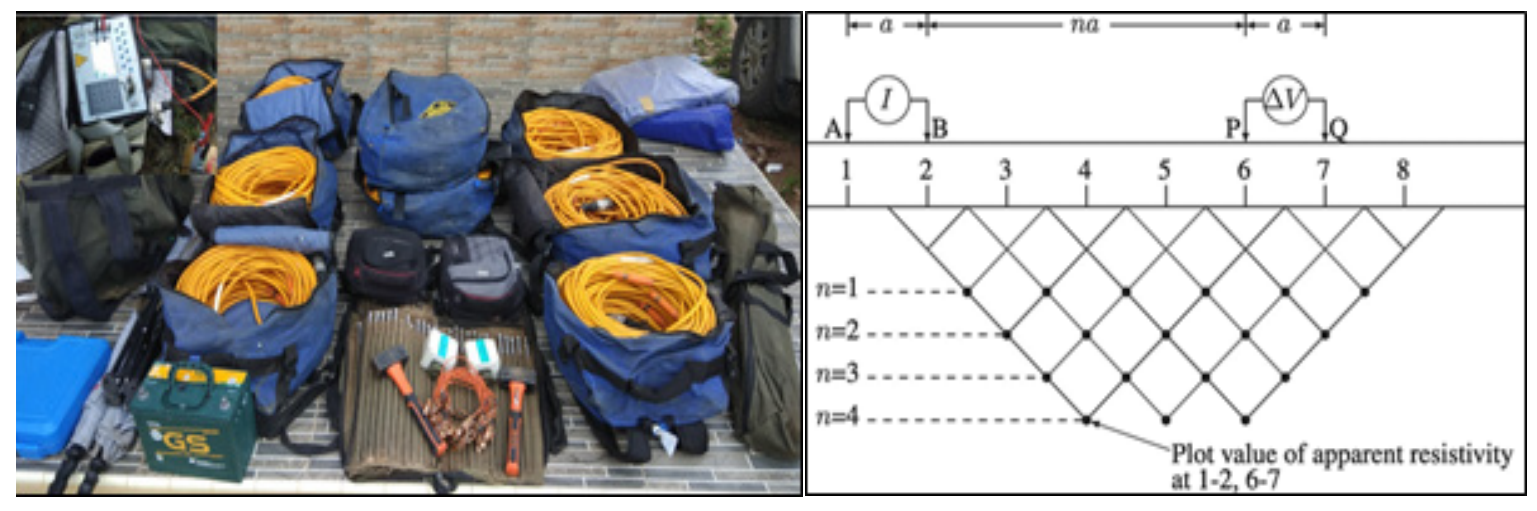

Figure 6. ERT IRIS Instruments (left) and the sequence of dipole-dipole measurement (right) 
Table 1. Electrical resistivity cluster and interpretation

\begin{tabular}{lcc}
\hline Resistivity (Ohm meter) & Lithology & Hydrogeology \\
\hline$<1.7$ & sandy clay, tuff (contain saline water in place) & saline water \\
$1.7-20$ & tuff, clay and silt stones & non-aquifer \\
$20-120$ & sandy clay, sandstone, tuffaceous sand and & aquitard - Aquifer \\
& peat & \\
$120-626$ & oxide gravels and breccia & non-aquifer \\
$>626$ & granite & aquifuge \\
\hline
\end{tabular}

of the aquifer (Figure 7, $8 \& 9$ ). The spacing between electrodes must be selected carefully so that the peat layer will not be hidden or generalized. The resistivity obtained from the ERT measurements varies from 0.2 to 7000 $\mathrm{ohm} \mathrm{m}$. The clustering of the resistivity value was made based on laboratory experiments (Loke, 2000)(Table 1).

\section{A. ERT Section PRG-2}

PRG-2 is located in peatland area. The area of measurement was surrounded by peat fires. The electrical resistivity obtained from the measurements varies from 0.34 to 445 -ohm meter (Figure 7). From local information, there was a dry hole well with a total depth of 40 $\mathrm{m}$ located in the middle of the line acquisition.
In this ERT section, the inversion result shows a relative conductive (less than 100-ohm meter) upper layer. This layer is correlated with the peat layer. Peat thickness varies from 2-5 meters. The wide variation on resistivity values depends on many physical properties of the peat. Groundwater level also affects the physical properties of the peat. (Walter, Lück, Heller, Bauriegel, \& Zeitz, 2019) have shown that different levels of water saturation strongly influence bulk electrical conductivity (reciprocal of resistivity). In dry season groundwater level fall far below the surface, thereby decreasing moisture contents of the surface peat and creating vast amounts of dry fuel that are a fire hazard (Wösten, Clymans, Page, Rieley, \& Limin, 2008).

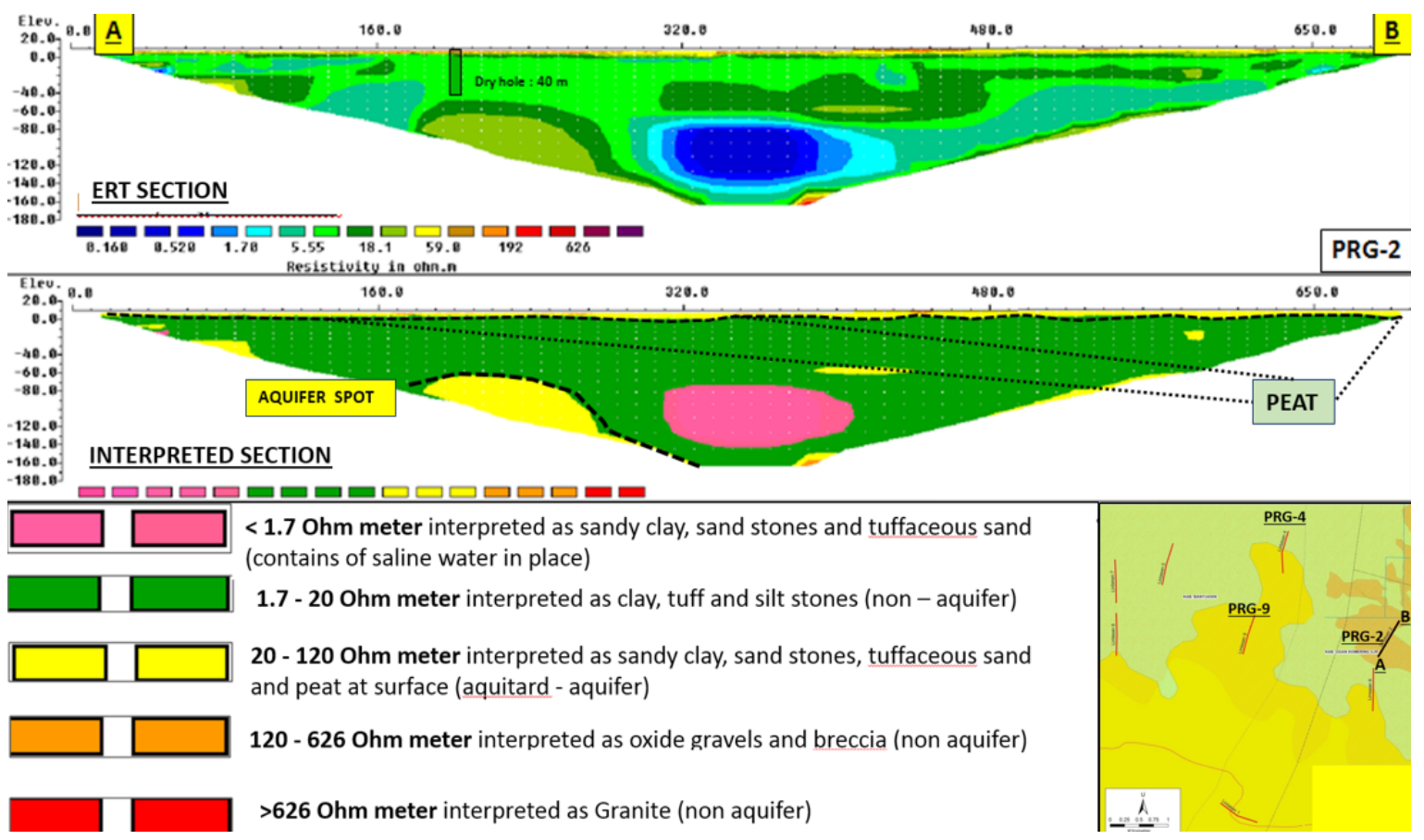

Figure 7. ERT PRG-4 section and its interpretation 
Some part of the peatland area was burnt and resulted in many large pores and cracks on the peat surface and its substrate. This condition may cause higher ash content of the peat and could make the resistivity value bigger than usual. The degree of peat decomposition will affect the electrical resistivity of peat. (Asadi \& Huat, 2009) with their resistivity laboratory tests have shown that the resistivity of peat decreased with the increasing degree of decomposition, water content, and temperature. Kurniain, Notohadikusumo, and Radjagukguk (2006) presented that development and cultivation in peatland caused changes in hydro-physical properties of peat soils. The hydro-physical properties of peat soil will affect electrical properties. The southern part of the line acquisition was converted to rubber plantation. The results of these laboratory experiments have not been explicitly confirmed by the ERT surveys presented in this paper.

Beneath the peat layer, the resistivity value varies from 1.7 to 20 -ohm meter. This layer can be interpreted as a clay layer which is confirmed from a dry hole well data. From this ERT section, we have located aquifer sweet spot in Kasai Formation. It was located at 60 to $120 \mathrm{~m}$ beneath the surface, Kasai formation composed of sandy clay, sandstone, tuffaceous sand, oxide gravel, and breccia. The resistivity of this layer varies from 20 to 120 -ohm meter. Resistivity value of less than 1-ohm meter was identified in this section. This value was correlated with saline water. Saline environments are mainly located in coastal zones, but they can also be found inland. Natural causes for salinization process are the presence of salt-rich rainwater or saline groundwater, high evaporation, and low precipitation. The main drivers for vertical salinity dynamics are precipitation and temperature (Walter, Lück, Bauriegel, Facklam, \& Zeitz, 2018).

\section{B. ERT Section ARB-1}

This section is located near the plantation area. This section is dominated by moderate to high resistivity values (Figure 8). The electrical resistivity obtained from the measurements varies from 0.32 to over $1000-$ ohm meter. Aquifer potential was identified in the

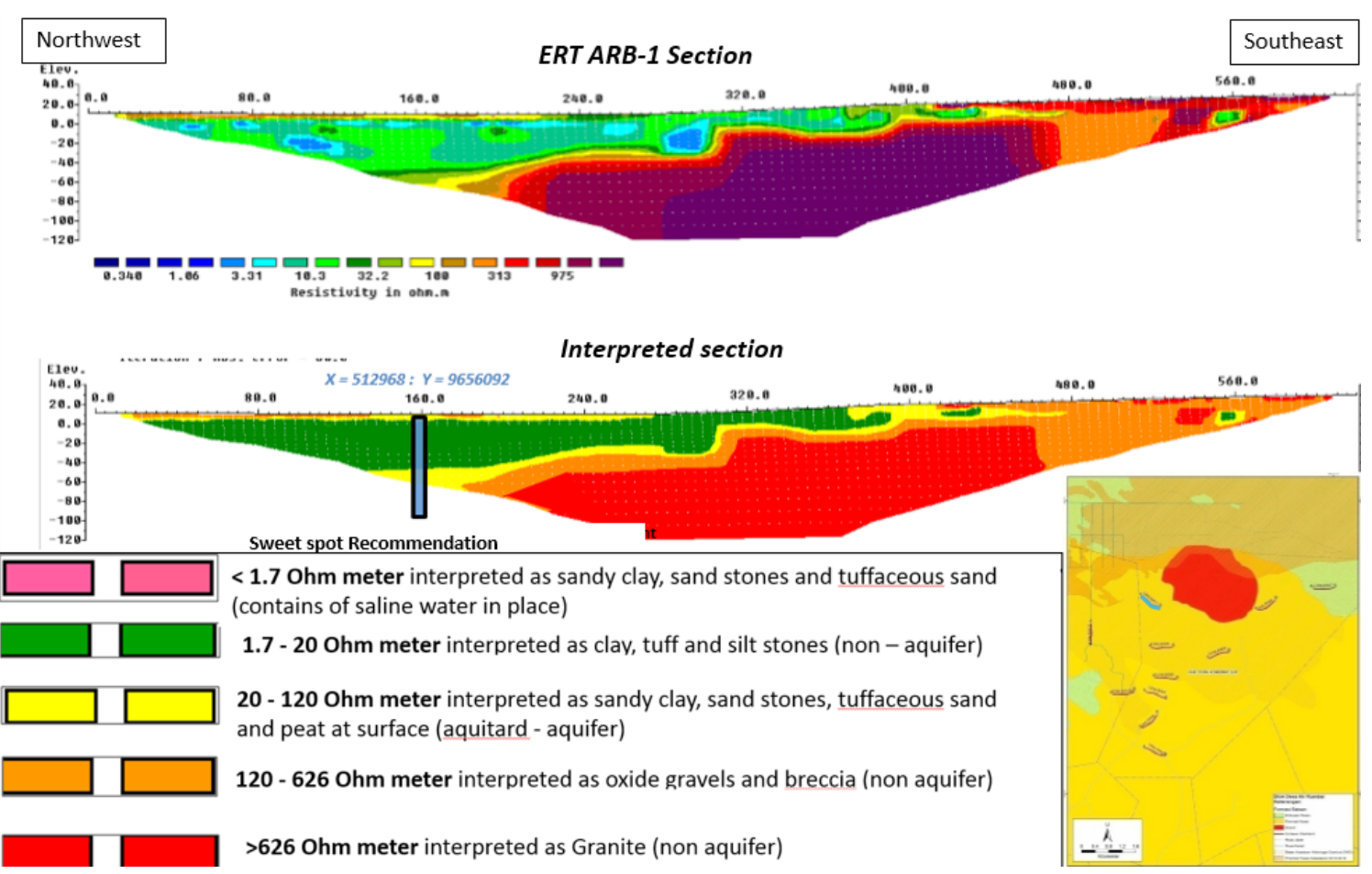

Figure 8. ERT ARB-2 section and its interpretation 
northwest of the section. The aquifer was identified in Kasai Formation. This sweet spot was predicted at 50 to $80 \mathrm{~m}$ beneath the surface. Electrical resistivity of this layer varies from 20 to 120 -ohm meter. The resistivity of this value can be interpreted as sandy clay, sandstones, and tuffaceous sand from Kasai Formation. The thickness of this layer varies from 5 to 20 meters. Overlaid the aquifer layer, the segment with low resistivity (1.7-20 ohm-meter) were identified form this section. This low resistivity value correlated with the clay layer. This low resistivity value is caused by surface conductivity of clay mineral. As clay minerals are flat, water can diffuse between the minerals and so increase the surface area. This condition supports the surface conductivity (Kirsch, 2009). High resistivity (>500 ohm-meter) values were obtained from this section. The resistivity of this value can be interpreted as a significant body of granite near the line of acquisition. Granite is an impermeable rock that wouldn't transfer any water (Fetter, 2001). Overlaid the granite, the aquifer thickened to the northwest side of the section. This interpretation is based on a literature study and the Geological Map of Tulung Selapan Area.

\section{ERT Section SBN-8}

This section is located in the peatland area. This section is dominated by low to moderate resistivity values (Figure 9). The electrical resistivity obtained from the measurements varies from 0.32 to $200-\mathrm{ohm}$ meter. The ERT measurement of this section differs with the ERT in Perigi and Air Rumbai Village. In this measurement, we have tested the ERT measurement with different electrode spacing along the same line of acquisition. We have experimented with $10 \mathrm{~m}$ (Figure 9a) and 2.5 $\mathrm{m}$ (Figure 9b) electrode spacing. From this section, we identified the peat layer at the upper layer. The resistivity of the peat layer varies from 70 to $>100 \mathrm{ohm}$-meter. The section with $2.5 \mathrm{~m}$ electrode spacing provided a better image of the peat layer. The high resistivity value of the peat layer correlated with many factors. The main factor is the physical properties of dried and burnt peat in the location of measurement. From this section, we can conclude that the ERT measurement with 2.5 m electrode spacing provided a better image than the ERT with 10 m spacing.

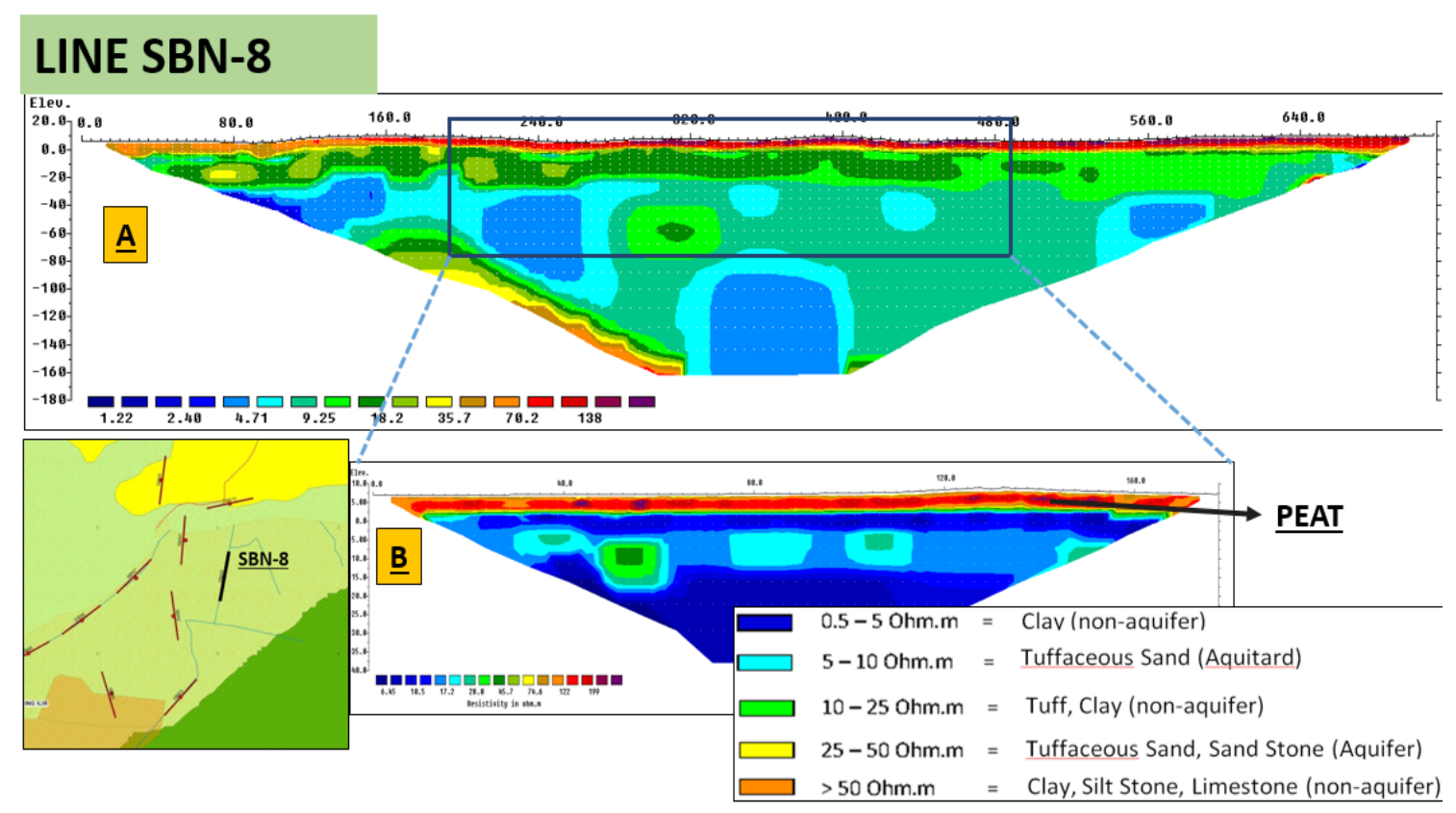

Figure 9. ERT SBN-8 section with $10 \mathrm{~m}$ (a) and $2.5 \mathrm{~m}$ (b) electrode spacing 


\section{CONCLUSION}

This study describes the application of electrical resistivity tomography for imaging subsurface of tropical peatland. The studies presented in this paper have cognitive and practical aspects. From ERT section, we identified physical properties of peat and its substrate. Electrical resistivity of peat varies from 20 to 120 -ohm meter at the surface. The thickness of peat varies from 1 to 5 meter. The electrical resistivity of peat depends on its physical properties such as water content, degree of decomposition, moisture and organic material and temperature. Aquifer sweet spot was located in the middle of PRG-2 and northwest side of ARB-1 section and was predicted at a depth of 60 to $100 \mathrm{~m}$ beneath the surface. The aquifer was identified in Kasai formation, which has low to moderate permeability. From SBN-10 section, we can identify the peat thickness from ERT section with $2.5 \mathrm{~m}$ electrode spacing. This spacing was recommended for imaging peatland using ERT method.

This study may support activities for tropical peatland conservation in Indonesia. Tropical peatland in swamp forests is most vulnerable from fire hazard during the dry season. Peat thickness and aquifer must be identified for tropical peatland conservation, especially for fire hazard mitigation. Electrical resistivity tomography and other non-invasive geophysical methods could help mapping subsurface of tropical peatland in Indonesia. These technologies, combined with direct sampling measurements, are the best method for characterizing peat physical properties, distribution, and thickness estimation.

\section{ACKNOWLEDGEMENT}

This study was a collaboration between the geological agency and peatland restoration agency. The peatland restoration agency funded this study. We are also thankful to Geological Agency survey team and Peatland Restoration Unit in South Sumatra for their cooperation, fieldwork guidance, and accommodation in the field site.

\section{REFERENCES}

Agus, F., Anda, M., Jamil, A., \& Masganti. (2014). Lahan gambut Indonesia: Pembentukan, karakteristik, dan potensi mendukung ketahanan pangan. Badan Penelitian dan Pengembangan Pertanian, Bogor.

Andriesse, J. P. (1988). Nature and managements of tropical peat soils. FAO Soils Bulletin, 59. Food and Agriculture Organization, Rome.

Asadi, A., \& Huat, B. B. K. (2009). Electrical resistivity of tropical peat. Electronic Journal of Geotechnical Engineering, 14 P, 1-9.

Bishop, M. G. (2001). South Sumatra Basin Province, Indonesia: The lahat/talang akar-cenozoic total petroleum system. doi://10.3133/ ofr9950S.

Cameron, C. C., Palmer, C. A., \& Esterle, J. S. (1990). The geology of selected peat-forming environments in temperate and tropical latitudes. International Journal of Coal Geology, 16(1-3), 127-130. doi://10.1016/01665162(90)90018-T.

CNN, I. (2019). Sehari 355 titik api di Sumsel, terbanyak sepanjang 2019. Retrieved from https: //www.cnnindonesia.com/ nasional/20190909004748-20-428609/ sehari-353-titik-api-di-sumsel-terbanyaksepanjang-2019 at October 15, 2019.

Comas, X., Terry, N., Slater, L., Warren, M., Kolka, R., Kristiyono, A., ... Darusman, T. (2015). Imaging tropical peatlands in Indonesia using ground-penetrating radar (GPR) and electrical resistivity imaging (ERI): implications for carbon stock estimates and peat soil characterization. Biogeosciences, 12(10), 2995-3007. doi://10.5194/bg-122995-2015.

Comas, Xavier, Slater, L., \& Reeve, A. (2004). Geophysical evidence for peat basin morphology and stratigraphic controls on vegetation observed in a Northern Peatland. Journal of Hydrology, 295(1-4), 173-184. doi://10.1016/j.jhydrol.2004.03.008. 
Comas, Xavier, Slater, L., \& Reeve, A. S. (2011). Pool patterning in a northern peatland: Geophysical evidence for the role of postglacial landforms. Journal of Hydrology, 399(3-4), 173-184. doi://10.1016/j. jhydrol.2010.12.031.

Darman, H., Sidi, F. H. (2000). An outline of the geology of Indonesia. Indonesian Association of Geologist, Jakarta.

De Coster, G. L. (1974). The geology of the central and south Sumatra Basins. In Proc. Indon Petrol. Assoc., $3^{\text {rd }}$ Ann. Conv. Jakarta: Indonesian Petroleum Association (IPA). doi://10.29118/IPA.670.77.110.

Fetter, C. W. (2001). Applied bydrogeology. Supplemental website. Retrieved from http://www. appliedhydrogeology. info. Upper Saddle River, NJ: Prentice Hall. Pearson Education Ltd. at September 17, 2019.

Hobbs, N. B. (1986). Mire morphology and the properties and behaviour of some British and foreign peats. Quarterly Journal of Engineering Geology and Hydrogeology, 19(1), 7-80. doi://10.1144/GSL.QJEG.1986.019.01.02.

Kirsch, R. (Ed.). (2009). Groundwater geophysics. Dictionary geotechnical engineering/worterbuch geotechnik. Berlin, Heidelberg: Springer Berlin Heidelberg. doi://10.1007/978-3-54088405-7.

Kittie, S., Schouten, G., \& Hein, L. (2018). The institutional fit of peatland governance in Indonesia. Land Use Policy. (In Press). doi://10.1016/j.landusepol.2018.03.031.

Kowalczyk, S., Zukowska, K. A., Mendecki, M. J., \& Lukasiak, D. (2017). Application of electrical resistivity imaging (ERI) for the assessment of peat properties: A case study of the Całowanie Fen, Central Poland. Acta Geophysica, 65(1), 223-235. doi://10.1007/ s11600-017-0018-9.

Kurniain, A., Notohadikusumo, T., \& Radjagukguk, B. (2006). Impact of development and cultivation on hydro-physical properties of tropical peat soils. Tropics, 15(4), 383-389. doi://10.3759/tropics.15.383.

Loke, M. H. (2000). Electrical imaging surveys for environmental and engineering studies. $A$ practical guide to 2-D and 3-d surveys. Retrieved from https://doi.org/10.3390/su8111117. at 18 September 2019.
Loke, Meng Heng. (2011). Electric resistivity surveys and data interpretation. In Encyclopedia of Earth Sciences Series (pp. 276-283). Springer. doi://10.1007/978-90-481-8702-7_46.

Mangga, S. A., Sukardi, \& Sidarto. (1993). Geological map of Tulung Selapan quadrangle. Scale 1: 250.000. Geological Research and Development Center, Bandung.

Osaki, M., Nursyamsi, D., Noor, M., Wahyunto, \& Segah, H. (2016). Peatland in Indonesia. In Tropical Peatland Ecosystems (pp. 49-58). Tokyo: Springer Japan. doi://10.1007/9784-431-55681-7_3.

Page, S. E., Rieley, J. O., \& Banks, C. J. . (2011). Global and regional importance of the tropical peatland carbon pool. Global Change Biology, 17(2), 798-818. doi://10.1111/ j.1365-2486.2010.02279.x.

Pasaribu, M., \& Mudiana, W. (2013). Hydrogeological map of Tulung Selapan quadrangle. Scale 1 : 250.000. Bandung: Geological Agency.

Putra, R., Sutriyono, E., Kadir, S., \& Iskandar, I. (2019). Understanding of fire distribution in the South Sumatra peat area during the last two decades. International Journal of GEOMATE, 16(54), 2186-2990. doi://10.21660/2019.54.8243.

Reynolds, J. M. (2011). An introduction to applied and environmental geophysics. John Wiley \& Sons, Ltd.

Rieley, J., \& Page, S. (2016). Tropical peatland of the world. In Tropical Peatland Ecosystems (pp. 3-32). Tokyo: Springer Japan. doi://10.1007/978-4-431-55681-7_1.

Sass, O., Friedmann, A., Haselwanter, G., \& Wetzel, K. F. (2010). Investigating thickness and internal structure of alpine mires using conventional and geophysical techniques. Catena, 80(3), 195-203. doi://10.1016/j. catena.2009.11.006.

Slater, L. D., \& Reeve, A. (2002). Investigating peatland stratigraphy and hydrogeology using integrated electrical geophysics. Geophysics, 67(2), 365-378. doi.://10.1190/1.1468597.

Subarnas, A., \& Ibrahim, A. (2018). Survei tinjau gambut Kabupaten Musi Banyuasin, Provinsi Sumatera Selatan. Pusat Sumber Daya Mineral Batubara dan Panas Bumi, Bandung.

SxEN, Z. (2015). Practical and applied bydrogeology. Elsevier. doi://10.1016/C2013-0-14020-2. 
Taufik, M., Veldhuizen, A. A., Wösten, J. H. M., \& van Lanen, H. A. J. (2019). Exploration of the importance of physical properties of Indonesian peatlands to assess critical groundwater table depths, associated drought and fire hazard. Geoderma, 347, 160-169. doi://10.1016/j.geoderma.2019.04.001.

Telford, W. M., Geldart, L. P., \& Sheriff, R. E. (1990). Applied geophysics. Cambridge University Press, Cambridge. doi://10.1180/ minmag.1982.046.341.32.

Trappe, J., \& Kneisel, C. (2019). Geophysical and sedimentological investigations of peatlands for the assessment of lithology and subsurface water pathways. Geosciences, 9(3), 118. doi://10.3390/geosciences9030118.

Wahyunto, Nugroho, K., \& Fahmuddin, A. (2014). Perkembangan Pemetaan dan Distribusi Lahan Gambut di Indonesia. In Lahan Gambut Indonesia: Pembentukan, karakteristik, dan potensi mendukung ketahanan pangan. Badan Penelitian dan Pengembangan Pertanian, Bogor.
Walter, J., Lück, E., Bauriegel, A., Facklam, M., \& Zeitz, J. (2018). Seasonal dynamics of soil salinity in peatlands: A geophysical approach. Geoderma, 310(August 2017), 1-11. doi://10.1016/j.geoderma.2017.08.022.

Walter, J., Lück, E., Heller, C., Bauriegel, A., \& Zeitz, J. (2019). Relationship between electrical conductivity and water content of peat and gyttja: implications for electrical surveys of drained peatlands. Near Surface Geophysics, 1-11. doi://10.1002/nsg.12030.

Wösten, J. H. M., Clymans, E., Page, S. E., Rieley, J. O., \& Limin, S. H. (2008). Peatwater interrelationships in a tropical peatland ecosystem in Southeast Asia. Catena, 73(2), 212-224. doi://10.1016/j. catena.2007.07.010.

Yoshino, T. (2011). Electrical properties of rocks.. In Encyclopedia of Earth Sciences Series (pp. 270-276). Springer. doi://10.1007/978-90481-8702-7_45. 